Provided for non-commercial research and education use. Not for reproduction, distribution or commercial use.

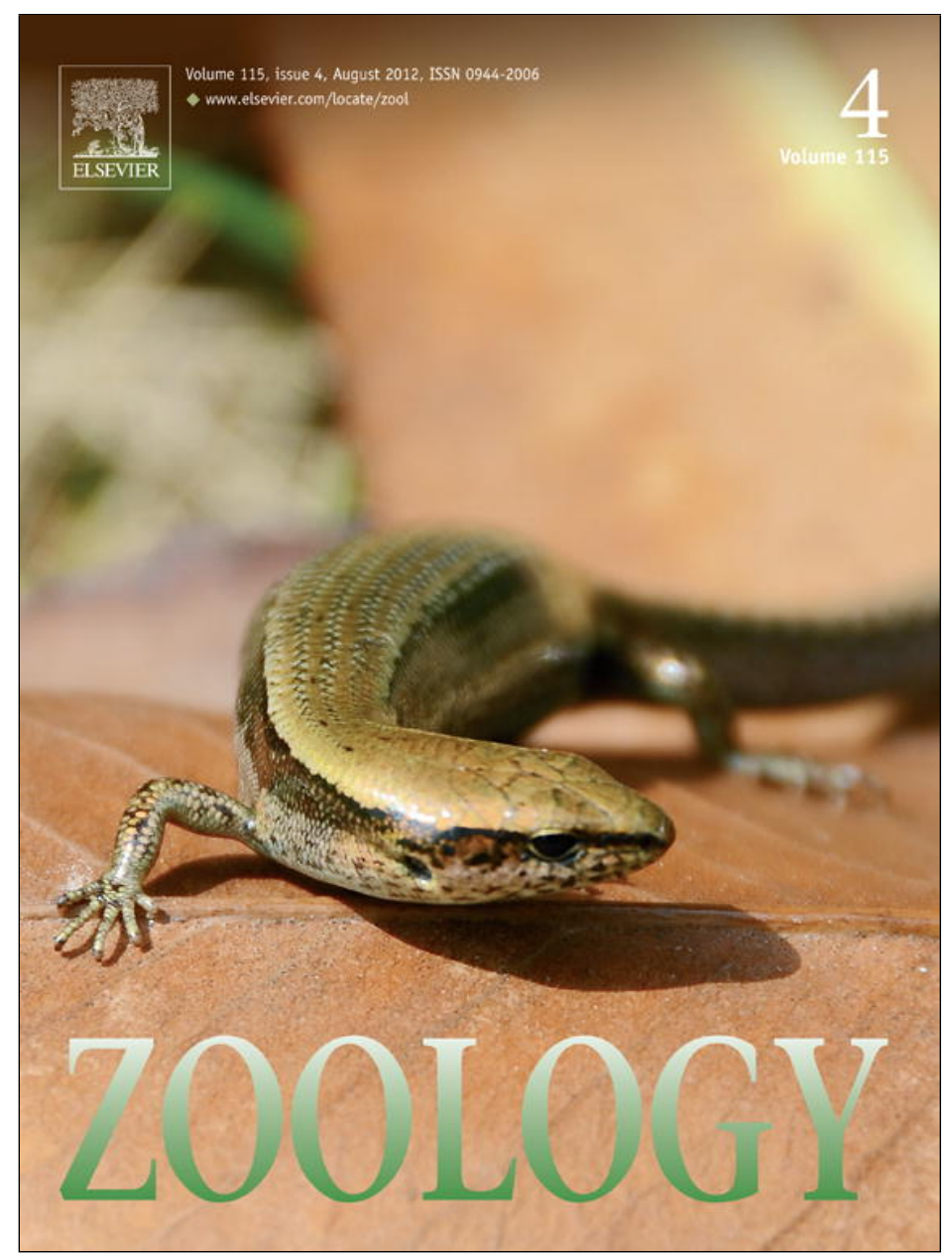

This article appeared in a journal published by Elsevier. The attached copy is furnished to the author for internal non-commercial research and education use, including for instruction at the authors institution and sharing with colleagues.

Other uses, including reproduction and distribution, or selling or licensing copies, or posting to personal, institutional or third party websites are prohibited.

In most cases authors are permitted to post their version of the article (e.g. in Word or Tex form) to their personal website or institutional repository. Authors requiring further information regarding Elsevier's archiving and manuscript policies are encouraged to visit:

http://www.elsevier.com/copyright 


\title{
Overlapping patterns of morphometric and genetic differentiation in the Mediterranean goby Pomatoschistus tortonesei Miller, 1968 (Perciformes, Gobiidae) in Tunisian lagoons
}

\author{
Randa Mejri $^{a}$, Sabrina Lo Brutto ${ }^{b, *}$, Nesrine Hassine ${ }^{a}$, Marco Arculeo $^{b}$, Oum Kalthoum Ben Hassine $^{a}$ \\ a Unité de Recherche de Biologie, Ecologie et Parasitologie des Organismes Aquatiques, Département de Biologie, Tunis El Manar 2092, Tunisia \\ b Dipartimento di Biologia Ambientale e Biodiversità, Università di Palermo, via Archirafi 18, Palermo 90123, Italy
}

\section{A R T I C L E I N F O}

\section{Article history:}

Received 26 November 2011

Received in revised form 15 January 2012

Accepted 16 February 2012

\section{Keywords:}

Gobiidae

Genetic diversity

Lagoon ecosystems

Mediterranean Sea

Morphometry

\begin{abstract}
A B S T R A C T
The genetic and morphological variations of Pomatoschistus tortonesei Miller, 1968 were studied in samples collected from three Tunisian lagoons. The morphological analysis included 18 morphometric measurements and was based on linear discriminant analysis (LDA), whereas the genetic analysis was based on the 16S-rRNA and COI mitochondrial genes. Both analyses differentiated the populations and demonstrated consistently a well-supported differentiation between the western Mediterranean samples (Bizerta and Tunis South lagoons) and the eastern Mediterranean sample (El Bibane lagoon). The observed differentiation could be explained in terms of the geographic isolation of the various populations and the influence of environmental factors, which differ greatly between the different sites. The molecular results revealed that the populations are characterised by unique haplotypes which are well defined in relation to limited gene flow and restricted dispersal abilities. Additionally, it seems that local selective pressures have modelled biometrical variation. Morphological results can reflect a differential habitat use revealed in the cephalic features and a different response to hydrodynamic constraints developed in dissimilar dorsal and pelvic fin lengths.
\end{abstract}

(c) 2012 Elsevier GmbH. All rights reserved.

\section{Introduction}

Coastal lagoons are complex dynamic ecosystems, characterised by a constant fluctuation of environmental conditions. There are numerous lagoons throughout the Mediterranean area, the majority having appeared during the Holocene period. These lagoons are well recognised as being unique in terms of biodiversity, and are possibly capable of producing and protecting more or less distinctive evolutionary lineages (e.g. Porter et al., 2001; Trabelsi et al., 2004).

One of the most predominant fish taxa to be found in Mediterranean lagoons is the genus Pomatoschistus Gill, 1844 of the Gobiidae family. One of these gobiine species is Pomatoschistus tortonesei Miller, 1968, which is endemic to the Mediterranean Sea and listed as an endangered species (Abdul Malak et al., 2011). Despite its particular situation, there is scant knowledge regarding its spatial distribution and only sporadic records have been reported, e.g. in the Marsala lagoon (Sicily, Italy)(Miller, 1968), the Farawa lagoon (Libya) (Miller, 1982) and in various Tunisian lagoons (Mejri et al.,

\footnotetext{
* Corresponding author. Tel.: +39 091 23891835; fax: +39 09123860855 .

E-mail address: sabrina.lobrutto@unipa.it (S. Lo Brutto).
}

2009a). P. tortonesei is a non-migratory, euryhaline species which spends its entire life in lagoons; benthic adults are considered poor swimmers because, as other gobies, their pelvic fins are fused in such a way as to form a suction disc (Miller, 1986).

Recent published results regarding the genetic structure of this species across its distribution range have revealed a significant divergence between the western and eastern Mediterranean populations, delimited by the Siculo-Tunisian Strait (STS) which acts as a breakpoint to gene flow in the Mediterranean Sea, and have shown a further degree of differentiation among western populations due to the hydrographic and ecological patterns of each locality (Mejri et al., 2009b). Despite such levels of genetic variation among populations, it is not yet known to what extent morphological and genetic differences correlate with each other.

It is known that morphological and genetic markers provide different but complementary information regarding population structure and this has been widely used in population differentiation studies and in stock assessments. Morphometric characters are partially genetically determined and they are strongly influenced by environmental conditions (Tudela, 1999; Turan, 2004). Thus, geographic isolation between populations is expected to promote the differentiation of both morphological and genetic characters, either due to drift or to different selective regimes related to 


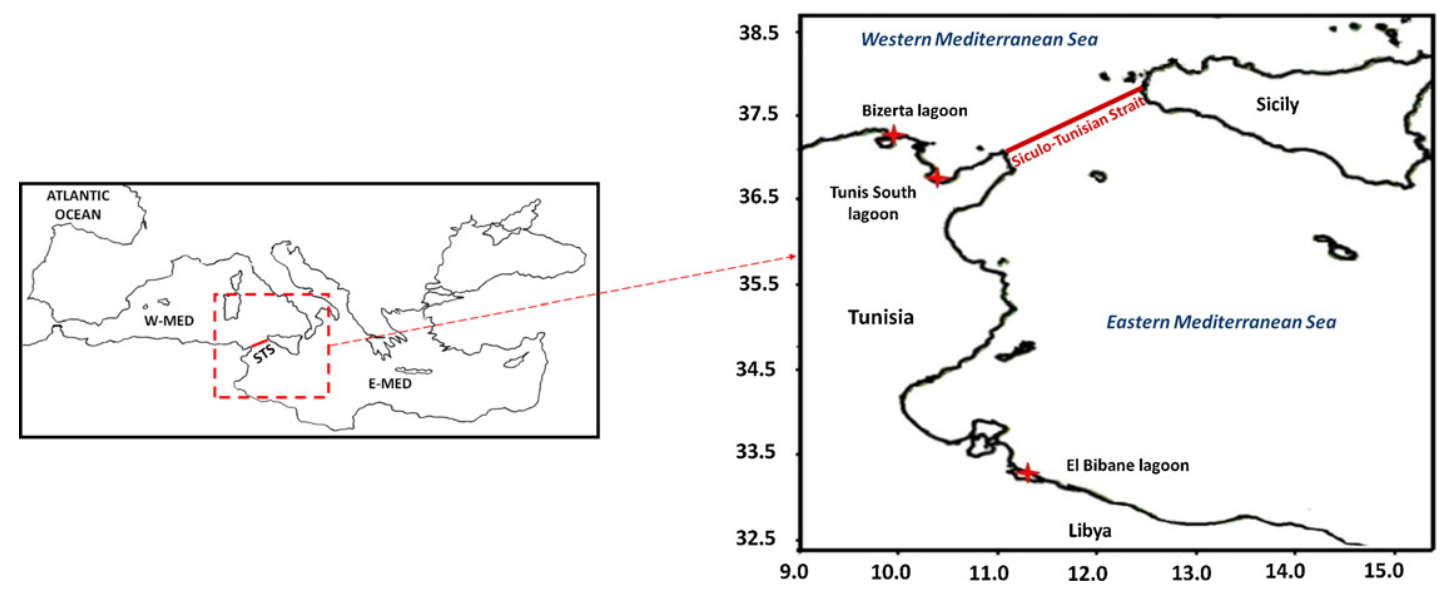

Fig. 1. Locations of the sampling sites in Tunisia: Bizerta lagoon (BIZ) and Tunis South lagoon (LST) in the western Mediterranean Sea (W-MED), El Bibane lagoon (BIB) in the eastern Mediterranean Sea (E-MED), divided by the Siculo-Tunisian Strait (STS).

environmental features (Slatkin, 1985). Consequently, population divergence may reflect insufficient gene flow and/or different selective pressures (Slatkin, 1985).

P. tortonesei is of particular interest in terms of evolution and adaptive radiation as it is well known that lagoons are characterised by wide variations in environmental parameters which may cause strong selective pressures on organisms. These factors, in association with geographic discontinuity, can play a key role in differentiating populations inhabiting these biotopes. In the light of these considerations, the available $m t$ DNA data previously reported by Mejri et al. (2009b) were compared with the morphometric measurements of the present study with the aim of: (i) comparing morphological and genetic differentiation; (ii) identifying and quantifying phenotypic variability and the evolutionary role of lagoons; and (iii) inferring the importance of lagoon environmental parameters in population structuring.

\section{Materials and methods}

\subsection{Sample collection}

Between April 2006 and March 2007 specimens of $P$. tortonesei were caught using a $10 \mathrm{~m}$ long purse seine with $0.5 \mathrm{~mm}$ mesh from three Tunisian coastal lagoons: the Bizerta lagoon (BIZ), the Tunis South lagoon (LST) and the El Bibane lagoon (BIB) (Fig. 1). The choice of these three sites was determined by ease of access and the abundance of the investigated species. The geographic coordinates of each mainland lagoon, their environmental features (Lemoalle, 1986; Sammari et al., 2006; Hlaili et al., 2008) and the numbers of individuals used in the present study are given in Table 1.

\subsection{Morphological analysis}

In total, 120 specimens of $P$. tortonesei were collected from the three lagoons (BIZ, LST and BIB). Eighteen morpho-anatomical parameters, including horizontal as well as vertical dimensions of the body, were measured: standard length (LS); head length (H); right eye diameter $(\mathrm{E})$; postorbital and interorbital length (PO and $\mathrm{IO})$; cheek depth (CHd); body height $(\mathrm{BH})$; first and second dorsal fin base lengths (D1 and D2); pectoral fin length (Pl); anal fin length (A); pelvic fin length $(\mathrm{Pv})$; distances from the snout to the origin of the first and second dorsal fins (SN/D1 and SN/D2); distance from the snout to the pectoral fin origin $(\mathrm{SN} / \mathrm{Pl})$; distance from the snout to the anal fin origin (SN/A); distance from the snout to the pelvic disc origin $(\mathrm{SN} / \mathrm{Pv})$ and the minimum height of the caudal peduncle (CP) (Fig. 2). All morphometric measurements were taken by the same person on the left lateral aspect and measured to the nearest $0.01 \mathrm{~mm}$.

For such analyses, it is important to eliminate any size effect especially when comparing fish of different sizes. Therefore, any size-dependent variation in morphometric characters was removed using the allometric approach by Reist (1985):

$M_{\text {trans }}=\log M-\beta\left(\log \mathrm{SL}-\log \mathrm{SL}_{\text {mean }}\right)$,

where $M_{\text {trans }}$ is the transformed measurement, $M$ is the original measurement, $\beta$ is the within-group slope regression of $\log M$ against $\log \mathrm{SL}, \mathrm{SL}$ is the standard length of the fish and $\mathrm{SL}_{\text {mean }}$ is the overall mean of the standard length. Morphometric characters were analysed together and a multivariate analysis of variance (MANOVA) was performed to test the significance of differences among groups.

In order to obtain an optimal set of characters for evaluating the extent to which geographic entities with different morphometric features could be separated, a linear discriminant analysis (LDA) was performed on the 120 individuals from the three sites. This analysis obtains linear combinations of variables (discriminant functions) which can be used to provide the best separation of classes. Wilk's criterion values were estimated to test the significance of such a discrimination for a combination of variables, and discriminant functions were used to classify individuals into

Table 1

Sample locations of Pomatoschistus tortonesei, geographic coordinates, environmental features, number of individuals per analysis and mean standard lengths (MSL, average \pm s.d.).

\begin{tabular}{|c|c|c|c|c|c|c|c|}
\hline \multirow{2}{*}{$\begin{array}{l}\text { Sampling } \\
\text { locations }\end{array}$} & \multirow{2}{*}{$\begin{array}{l}\text { Geographic } \\
\text { coordinates }\end{array}$} & \multicolumn{3}{|c|}{ Environmental features } & \multicolumn{2}{|l|}{ Sample sizes } & \multirow[t]{2}{*}{$\operatorname{MSL}(\mathrm{cm})$} \\
\hline & & Substrata & $\begin{array}{l}\text { Vegetation } \\
\text { encountered }\end{array}$ & Tide amplitude & Genetic study & $\begin{array}{l}\text { Morphometric } \\
\text { study }\end{array}$ & \\
\hline Bizerta & $37^{\circ} 13^{\prime} \mathrm{N} 9^{\circ} 51^{\prime} \mathrm{E}$ & Muddy + biodetritus & Algae & $0.02-0.13 \mathrm{~m}$ & 10 & $39\left(40^{2} 350\right)$ & $2.90 \pm 0.31$ \\
\hline Tunis South & $36^{\circ} 47^{\prime} \mathrm{N} 10^{\circ} 14^{\prime} \mathrm{E}$ & Muddy & Algae & $0.4 \mathrm{~m}$ & 7 & 33 (20 31ㅇ) & $2.45 \pm 0.17$ \\
\hline El Bibane & $33^{\circ} 16^{\prime} \mathrm{N} 11^{\circ} 17^{\prime} \mathrm{E}$ & Sandy + biodetritus & Cymodocea nodosa & $1.8 \mathrm{~m}$ & 9 & $48\left(10^{7} 470+\right)$ & $2.69 \pm 0.19$ \\
\hline
\end{tabular}



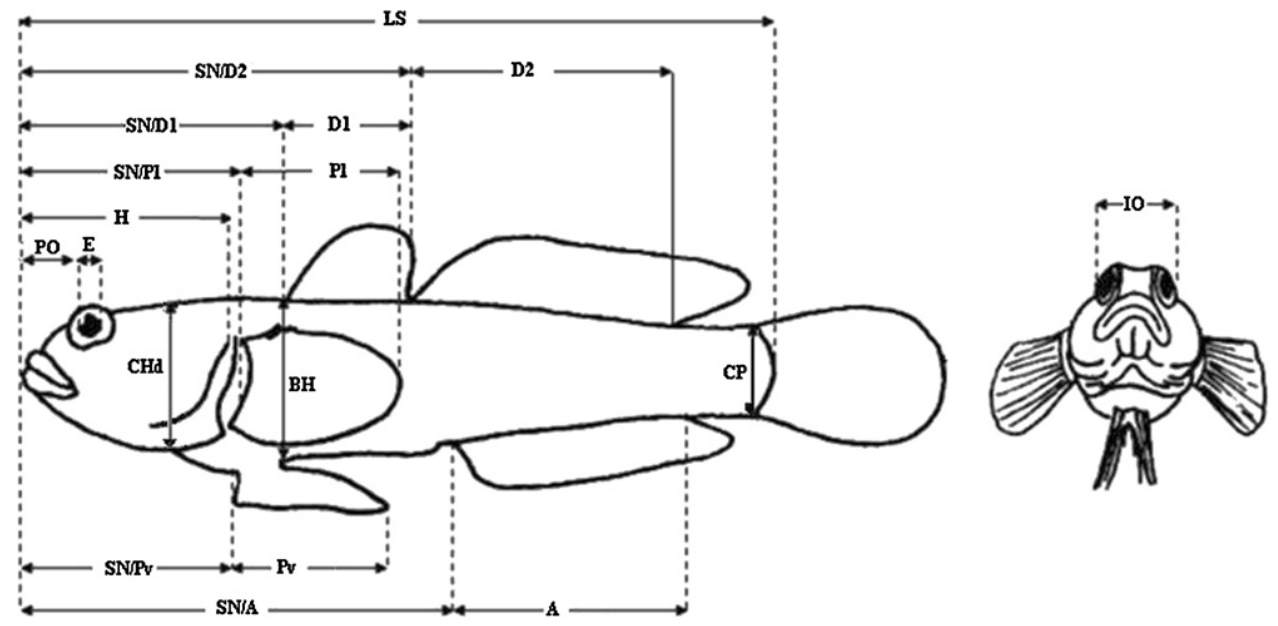

Fig. 2. Morphometric measurements (see text for details).

samples. The classification success rate (PCS) representing the percentage of individuals which were correctly assigned to the original sample was evaluated.

All calculations and graphs were made with Minitab 12.2 and $\mathrm{R}$ 2.8.1 software. The packages used were "ade4" (Chessel et al., 2004), Mass (Venables and Ripley, 2002), Stats (R Development Core Team, Vienna, and contributors worldwide) and Ape (Paradis et al., 2004).

\subsection{Genetic analysis}

For molecular analyses, 26 previously obtained sequences of P. tortonesei (Mejri et al., 2009b) were used. The data set contained samples from the three lagoons investigated in the present study. The procedure, which has already been reported in Mejri et al. (2009b), is briefly summarised here. Total DNA was extracted from analysed specimens and a fragment of both the mitochondrial $16 S$ ribosomal RNA gene (16S-rDNA, $518 \mathrm{bp}$ ) and the cytochrome oxidase I gene (COI, $648 \mathrm{bp}$ ) were amplified. Levels of haplotypic diversity $h$ (Nei, 1987) and nucleotide diversity $\pi$ (Tajima, 1993) were calculated using DnaSP v. 4.50 (Rozas et al., 2003). Phylogeographic analyses were performed, using the UPGMA method, with the software MEGA v. 4 (Tamura et al., 2007). The tree was rooted with co-genus Pomatoschistus marmoratus haplotypes originating from Tunisia. Node robustness was estimated by running bootstrap tests with replicates encompassing 1000 data sets.

\section{Results}

\subsection{Morphological analysis}

The MANOVA for the 18 biometric characters revealed highly significant average differences $(p<0.001)$ among localities, leading to the rejection of the null hypothesis of 'no heterogeneity'. The LDA of $P$. tortonesei's log-transformed variables yielded two initial factorial axes, accounting for $86.49 \%$ and $13.51 \%$ of total variance, respectively. Hence, the two discriminant functions LD1 and LD2 were chosen for the analyses.

Plotting these two discriminant functions resulted in a distinction among the three studied lagoons (Fig. 3A). The first two groups were spread along LD2 and were composed of individuals originating from BIZ and LST from the north of Tunisia. The third group, which projected onto the positive side of LD1, represented the sample from BIB, which is located on the south coast. The significance of the inter-group variability between the lagoon samples was proven by Wilk's criterion (Wilk's $\lambda=0.07, F=16.80, p<0.001$ ).
Table 2

Classification success rate (PCS) evaluated according to the percentage of Pomatoschistus tortonesei individuals correctly assigned to the original sample. BIZ: Bizerta lagoon; LST: Tunis South lagoon; BIB: El Bibane lagoon. $N=$ sample size.

\begin{tabular}{lccr}
\hline Sample & BIZ & LST & BIB \\
\hline BIZ & 35 & 4 & 0 \\
LST & 4 & 29 & 0 \\
BIB & 0 & 0 & 48 \\
$N$ total & 39 & 33 & 48 \\
$N$ correct & 35 & 29 & 48 \\
Proportion & 89.7 & 87.9 & 100 \\
\hline
\end{tabular}

The most important discriminative characters in distinguishing between the groups were pelvic fin length $(\mathrm{Pv})$ and the second dorsal fin length (D2) (Fig. 3C and D), both of which contributed to defining the first discriminating function, LD1. Cheek depth (CHd) and head length (H) (Fig. 3B), which characterise the cephalic region of the body, defined the second axis, LD2.

Using these morphometric characters, the discriminating analysis correctly classified 112 of the 120 fishes (i.e. 93.3\%), while the cross-validation testing procedure correctly classified 105 of 120 fishes (i.e. 87.5\%). The proportion of specimens correctly classified into their original group was highest (100\%) for BIB (Table 2 ).

\subsection{Genetic analysis}

Values relating to indexes of general genetic diversity are reported in Table 3. It is noteworthy that the different populations under investigation presented private haplotypes which were only found in a single locality.

The UPGMA tree revealed a split between two highly divergent groups with no geographical overlap and a high bootstrap value (100\%) (Fig. 4). The first clade was represented by the western Mediterranean samples from BIZ and LST, whereas the second clade was formed by the eastern Mediterranean sample from BIB. On a local scale, the neighbouring populations from BIZ and LST presented a further segregation within the major clade, appearing as separated sub-groups (Fig. 4). Thus, all haplotypes were related according to their geographic area of occurrence, and their topology was consistent with the degree of morphometric differentiation.

\section{Discussion}

The results from genetic and morphological analyses provided congruent evidence for a significant differentiation between all 

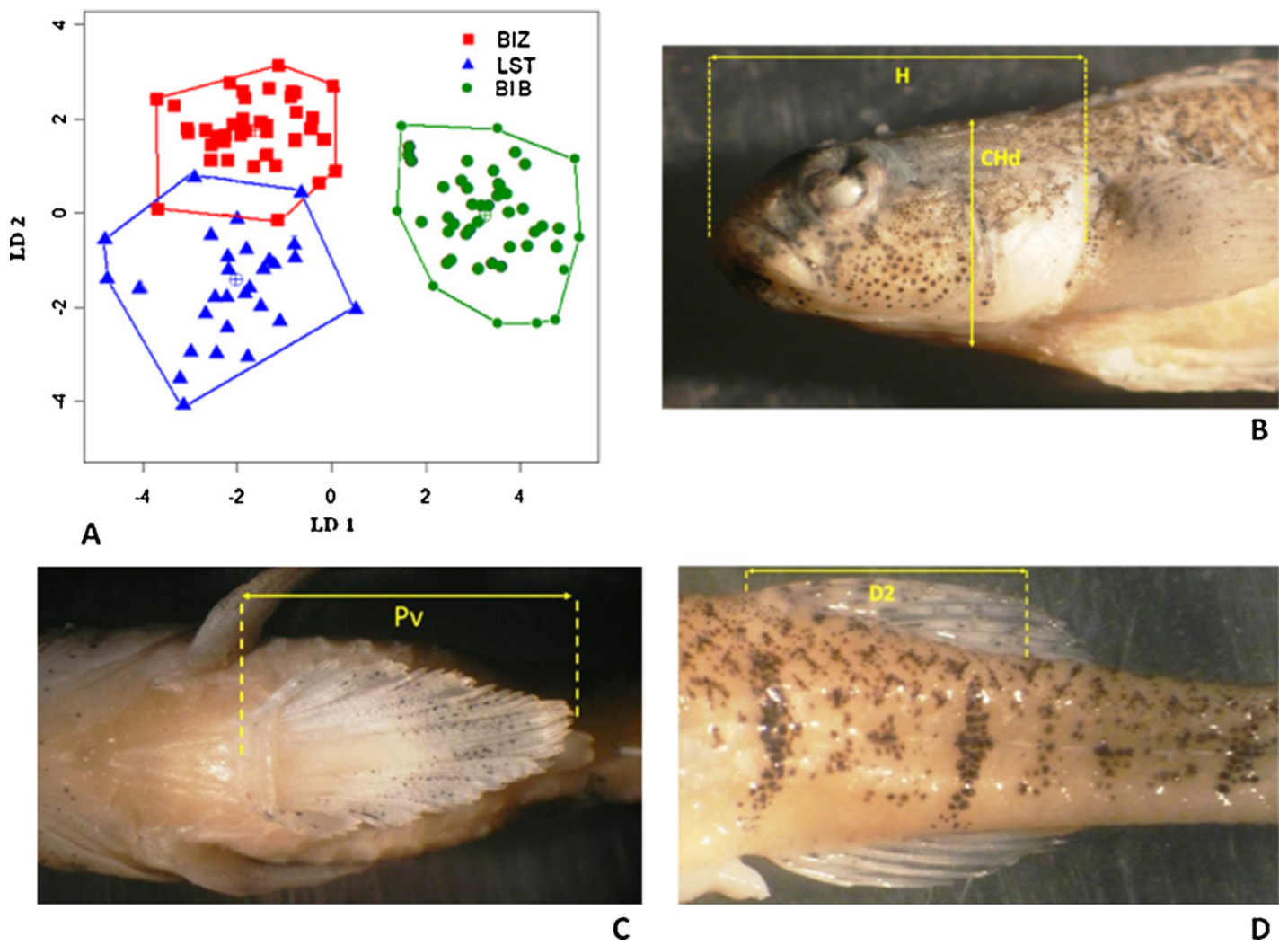

Fig. 3. (A) Plot of the linear discriminant analysis on the first plane (LD1, LD2) for the three lagoon samples: Bizerta lagoon (BIZ), Tunis South lagoon (LST) and El Bibane lagoon (BIB). (B) The parameters cheek depth (CHd) and head length $(\mathrm{H})$, which contribute to LD2. (C and D) The parameters pelvic fin length (Pv) and second dorsal fin length (D2), which contribute to LD1.

Table 3

Genetic variability of 16S-rRNA and COI sequences detected in Pomatoschistus tortonesei samples.

\begin{tabular}{|c|c|c|c|c|c|c|}
\hline \multirow[b]{2}{*}{ Locus } & \multicolumn{2}{|c|}{ Bizerta lagoon } & \multicolumn{2}{|c|}{ Tunis South lagoon } & \multicolumn{2}{|c|}{ El Bibane lagoon } \\
\hline & $16 S$ & $\mathrm{COI}$ & $16 S$ & $\mathrm{COI}$ & $16 S$ & $\mathrm{COI}$ \\
\hline Sample size $(N)$ & 10 & 10 & 7 & 7 & 9 & 9 \\
\hline Segregating sites (SS) & 2 & 1 & 2 & 1 & 2 & 4 \\
\hline Number of haplotypes $\left(N_{h}\right)$ & 3 & 2 & 3 & 2 & 3 & 4 \\
\hline Nucleotide diversity $(\pi)$ & 0.0010 & 0.0005 & 0.0014 & 0.0004 & 0.0008 & 0.0018 \\
\hline Haplotypic diversity $(h)$ & 0.5111 & 0.3555 & 0.6666 & 0.2857 & 0.4166 & 0.7500 \\
\hline
\end{tabular}

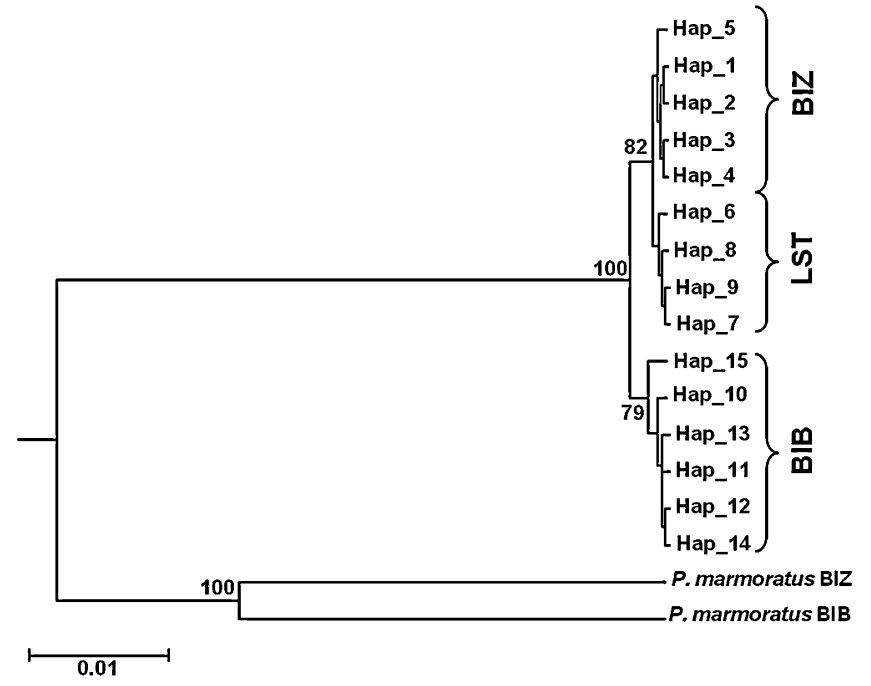

Fig. 4. Nucleotide divergence from $16 S-r D N A+C O I$ sequences, clustered by UPGMA (numbers indicate the percentage of 1000 bootstrap replicates that support each branch). BIZ: Bizerta lagoon; LST: Tunis South lagoon; BIB: El Bibane lagoon. three samples, and, most predominantly, between the western vs. eastern Mediterranean areas, which correspond to the northern (BIZ and LST) and southern coasts of Tunisia (BIB), respectively. The role of the STS, which separates the gene pool of the western from that of the eastern Mediterranean samples, has been widely discussed in previous papers (Mejri et al., 2009b, 2011). Here, the dataset allows an additional differentiation with regard to morphometric data which is congruent with the genetic pattern.

A consideration of the various analysed metric parameters reveals the discriminating value of some of the samples. The causes of morphological differences between populations can often be quite difficult to explain. However, most authors agree that variations in environmental conditions play the largest part in determining morphological variation and phenotypic discreteness (Norton et al., 1995; Wainwright, 1996). Either these particular designs have been fostered by natural selection (because they are more appropriate than the alternatives), or they are particularly economical in terms of energy or materials (Alexander, 1988).

According to the LDA results (Fig. 3A), three phenotypically diverse groups could be distinguished, and a strong discrepancy between the $P$. tortonesei populations from the north of Tunisia $(\mathrm{BIZ}+\mathrm{LST})$ and the population from southern Tunisia (BIB) was 
found. The whole LDA pattern is the result of the variation detected in the following characters: cheek depth $(\mathrm{CHd})$ and head length $(\mathrm{H})$, which have had the major weight in the discrimination on the LD2 axis, and dorsal (D2) and pelvic (Pv) fin lengths, which can be considered responsible for the discrimination on the LD1 axis (Fig. 3). According to the results, BIB specimens have the longest fins while the western populations, BIZ and LST, have the larger amplitude of variation in head shape.

Various authors have studied the intra-specific variation of head morphology and different trophic uses in marine fishes, such as carangids (Turan, 2004), labrids (Westneat, 1995; Wainwright et al., 2004) and sparids (Sarà et al., 1999; Hammami et al., 2011). These authors suggest that a detailed study of cephalic morphology and body shape could reveal different trophic groups. The morphological discrepancy in head traits may reflect a differential habitat use, especially regarding the exploitation of different ecological niches with variable diets (Hyndes et al., 1997; Delariva and Agostinho, 2001). In general, the link between morphology and diet in fish is provided by feeding performance (Norton, 1991; Wainwright, 1991; Motta and Kotrschal, 1992). For example, head morphology is subject to various constraints determined by the feeding strategy and the type and size of ingested food (Gatz, 1979; Wainwright and Richard, 1995).

For the present study, the nature of the substrata and their cover has been investigated at all sampling sites (Table 1). P. tortonesei from the northern Tunisian lagoons (BIZ and LST) were collected in muddy vegetated substrata where grasses abound, offering a good biotope for amphipods and ostracods, which are the preferred prey of this fish (Miller, 1982; personal observations). In the south (BIB), in contrast, this species was plentiful only in sandy areas lacking in vegetation and characterised by prey depletion. Specimens could have adapted their head size and shape according to food availability or density, and to the type and size of prey in relation to algal cover.

In addition to differences in cephalic features, we also observed morphological discrepancies in dorsal (D2) and pelvic (Pv) fin lengths. It is well known that soft dorsal fins act as a static keel or body stabiliser, generating thrust and lateral forces during locomotion. During turning manoeuvres, dorsal fins become a fixed pivot point for body rotation. The soft dorsal fins also play a significant role in steady propulsion and generate a large, lateral force (Drucker and Lauder, 2001, 2005). Along with the caudal and anal fins, the paired pelvic fins permit fish to swim steadily forwards with minimal roll and yaw (Drucker and Lauder, 2005). In gobiid species, the pelvic fins are fused into a suctorial disk which assists them in attaching themselves firmly to rocks, preventing them from being swept away by swift currents (Miller, 1986). Thus, various fins are used by fish to move and stabilise their bodies when suspended in turbulent flow. The range of stability conferred by the fins may cause body shape and habitat specialisation to play a lesser role in swimming in turbulence than in steady flow (Bioly and Magnan, 2002).

When considering the differences in hydrodynamic constraints (i.e. tide currents) in the lagoons under investigation (Table 1), we noticed that hydrographic currents are of great importance, participating actively in the circulation, turbulence flow and renewal of water masses, particularly in El Bibane lagoon (BIB). These conditions provide a stimulus for benthic species with a 'homing' behaviour (such as P. tortonesei) to develop and increase their fixation surface and stability organs in order to thwart drift through tidal currents and to be able to act in sudden perturbations. Indeed, fish subjected to complex flows normally demonstrate an ability to maintain stability, which can be achieved either passively by self-correcting mechanisms or actively through the powered movements of fins (Webb and Weihs, 1994; Jindrich and Full, 2002; Liao, 2002; Webb, 2004). The shape of the body and the posture of fins and their intrinsic compliance can also contribute to passive mechanisms of stability (Liao, 2007).

However, the biometric differences among populations of $P$. tortenesei from the three different lagoons may reflect not only phenotypic plasticity but also the effect of geographic isolation. Molecular analyses confirmed such a scenario. Previous studies (Mejri et al., 2009b) have demonstrated that no haplotypes were shared between the three populations under investigation, implying that there was no gene flow between them (Fig. 4). The pattern described by the UPGMA tree is consistent with the degree of morphometric differentiation.

The current genetic structure of $P$. tortonesei, a species which exclusively inhabits lagoons, could be the product of an increasing divergence of lineages producing morphologically different forms. It can be assumed that a restricted gene flow between populations has constrained $P$. tortonesei populations to adapt and evolve as independent entities in different environmental conditions. Specifically, as $P$. tortonesei is strictly associated with lagoon habitats, which are transitional environments and characterised by an instability of their physico-chemical parameters (Sarà, 2009), it could have been exposed to selective pressures more frequently than marine species which inhabit open-sea habitats. Such selective pressures could have amplified pre-existent, morphological traits, especially since $P$. tortonesei is a benthic species with low dispersal abilities and short pelagic larval stages. Brackish water ecosystems are often exposed to wide variations in environmental parameters, a fact which may cause strong selective pressures on organisms (e.g. Trabelsi et al., 2004). In association with genetic and geographical discontinuity, these pressures can play an important role in separating species inhabiting these environments into different populations.

\section{Acknowledgements}

The authors are grateful to two anonymous reviewers and the Editorial Office who provided valuable suggestions and comments during revision of the manuscript. This research was supported by the Ministry of Education, Scientific Research and Technology of the Republic of Tunisia and by the University of Palermo (Fondi di Ateneo).

\section{References}

Abdul Malak, D., Livingstone, S.R., Pollard, D., Polidoro, B.A., Cuttelod, A., Bariche, M. Bilecenoglu, M., Carpenter, K.E, Collette, B. B, Francour, P. Goren, M., Kara, M.H., Massutí, E., Papaconstantinou, C., Tunesi, L., 2011. Overview of the Conservation Status of the Marine Fishes of the Mediterranean Sea. IUCN, Gland, Switzerland and Malaga, Spain

Alexander, R.McN., 1988. The scope and aims of functional and ecological morphology. Neth. J. Zool. 38, 3-22.

Bioly, P., Magnan, P., 2002. Relationship between individual variation in morphological characters and swimming costs in brook char (Salvelinus fontinalis) and yellow perch (Perca flavescens). J. Exp. Biol. 205, 1031-1036.

Chessel, D., Dufour, A.B., Thioulouse, J., 2004. The ade4 package. I: One-table methods. R News 4, 5-10.

Delariva, R.L., Agostinho, A.A., 2001. Relationship between morphology and diets of six neotropical loricariids. J. Fish Biol. 58, 832-847.

Drucker, E.G., Lauder, G.V., 2001. Locomotor function of the dorsal fin in teleos fishes: experimental analysis of wake forces in sunfish. J. Exp. Biol. 204, 2943-2958.

Drucker, E.G., Lauder, G.V., 2005. Locomotor function of the dorsal fin in rainbow trout: kinematic patterns and hydrodynamic forces. J. Exp. Biol. 208, 4479-4494.

Gatz, A.J., 1979. Ecological morphology of freshwater stream fishes. Tulane Stud. Zool. Bot. 21, 91-124.

Hammami, I., Bahri-Sfar, L., Ben Hassine, O.K., 2011. Morphological variations of striped seabream, Lithognathus mormyrus, populations along the Tunisian coast. J. Mar. Biol. Assoc. UK 91, 1261-1271.

Hlaili, S.A., El Grami, B., Niquil, N., Gosselin, M., Hamel, D., Troussellier, M., Hadj Mabrouk, H., 2008. The planktonic food web of the Bizerte lagoon (southwestern Mediterranean) during summer. I: Spatial distribution under different anthropogenic pressures. Estuar. Coast. Shelf Sci. 78, 61-77. 
Hyndes, G.A., Platell, M.E., Potter, I.C., 1997. Relationships between diet and body size, mouth morphology, habitat and movement of six sillaginid species in coastal waters: implications for resource partitioning. Mar. Biol. 128, 585-598.

Jindrich, D.L., Full, R.B., 2002. Dynamic stabilization of rapid hexapedal locomotion. J. Exp. Biol. 205, 2803-2823.

Lemoalle, J., 1986. Etude de la lagune El Bibane. I: Les conditions du Milieu. Publication trimestrielle de l'Institut national scientifique et technique d'océanographie et de pêche de Salammbô, Rapport $\mathrm{N}^{\circ} 2$.

Liao, J.C., 2002. Swimming in needlefish (Belonidae): anguilliform locomotion with fins. J. Exp. Biol. 205, 2875-2884.

Liao, J.C., 2007. A review of fish swimming mechanics and behaviour in altered flows. Philos. Trans. R. Soc. B 362, 1973-1993.

Mejri, R., Menif, D., Louiz, I., Ben Hassine, O.K., 2009a. First record of Tortonese's goby, Pomatoschistus tortonesei Miller, 1968, in Tunisian lagoons. Cybium 33 , 85-87.

Mejri, R., Lo Brutto, S., Ben Hassine, O.K., Arculeo, M., 2009b. A study on Pomatoschistus tortonesei Miller, 1968 (Perciformes, Gobiidae) reveals the Siculo-Tunisian Strait (STS) as a breakpoint to gene flow in the Mediterranean basin. Mol. Phylogenet. Evol. 53, 596-601.

Mejri, R., Arculeo, M., Ben Hassine, O.K., Lo Brutto, S., 2011. Genetic architecture of the marbled goby Pomatoschistus marmoratus (Perciformes, Gobiidae) in the Mediterranean Sea. Mol. Phylogenet. Evol. 58, 395-403.

Miller, J.P., 1968. A new species of Pomatoschistus (Teleostei: Gobiidae) from western Sicily. Ann. Mus. Civ. Stor. Nat. Genova 77, 221-231.

Miller, J.P., 1982. A new Pomatoschistus from Mediterranean, and redescription of P. tortonesei, Miller, 1968. Senckenberg. Biol. 62, 5-19.

Miller, J.P., 1986. The family of Gobiidae. In: Whitehead, P.J.P., Bauchot, M.L., Hureau, J.C., Nielson, J., Tortonese, E. (Eds.), Fishes of the North Eastern Atlantic and of the Mediterranean, vol. 3. UNESCO, Paris, pp. 1019-1085.

Motta, P.J., Kotrschal, K.M., 1992. Correlative, experimental, and comparative experimental approaches in ecomorphology. Neth. J. Zool. 42, 400-415.

Nei, M., 1987. Molecular Evolutionary Genetics. Columbia University Press, New York.

Norton, S.F., 1991. Capture success and diet of cottid fishes: the role of predator morphology and attack kinematics. Ecology 72, 1807-1819.

Norton, S.F., Luczkovich, J.J., Motta, P.J., 1995. The role of ecomorphological studies in the comparative biology of fishes. Environ. Biol. Fish. 44, 287-304.

Paradis, E., Claude, J., Strimmer, K., 2004. APE: analyses of phylogenetics and evolution in R language. Bioinformatics 20, 289-290.

Porter, J.S., Dyrynda, P.E.J., Ryland, J.S., Carvalho, G.R., 2001. Morphological and genetic adaptation to a lagoon environment: a case study in the bryozoan genus Alcyonidium. Mar. Biol. 139, 575-585.

Reist, J.D., 1985. An empirical evaluation of several univariate methods that adjust for size variation in morphometric variation. Can. J. Zool. 63, 1429-1439.
Rozas, J., Sánchez-Delbarrio, J.C., Messeguer, X., Rozas, R., 2003. DnaSP, DNA polymorphism analyses by the coalescent and other methods. Bioinformatics 19 , 2496-2497.

Sammari, C., Koutitonsky, V., Moussa, M., 2006. Sea level variability and tidal resonance in the Gulf of Gabès, Tunisia. Cont. Shelf Res. 26, 338-350.

Sarà, G., 2009. Variation of suspended and sedimentary organic matter with depth in shallow coastal waters. Wetlands 29, 1234-1242.

Sarà, M., Favarolo, E., Mazzola, A., 1999. Comparative morphometrics of sharpsnout seabream (Diplodus puntazzo Cetti, 1777) reared in different conditions. Aquacult. Eng. 19, 195-209.

Slatkin, M., 1985. Gene flow in natural populations. Annu. Rev. Ecol. Evol. Syst. 16, 393-430.

Tajima, F., 1993. Simple methods for testing the molecular evolutionary clock hypothesis. Genetics 135, 599-607.

Tamura, K., Dudley, J., Nei, M., Kumar, S., 2007. MEGA 4: molecular evolutionary genetics analysis (MEGA) software version 4.0. Mol. Biol. Evol. 24, 1596-1599.

Trabelsi, M., Maamouri, F., Quignard, J.-P., Boussaïd, M., Faure, E., 2004. Morphometric or morpho-anatomical and genetic investigations highlight allopatric speciation in Western Mediterranean lagoons within the Atherina lagunae species (Teleostei, Atherinidae). Estuar. Coast. Shelf Sci. 61, 713-723.

Tudela, S., 1999. Morphological variability in a Mediterranean, genetically homogeneous population of the European anchovy, Engraulis encrasicolus. Fish. Res. 42 229-243.

Turan, C., 2004. Stock identification of Mediterranean horse mackerel (Trachurus mediterraneus) using morphometric and meristic characters. ICES J. Mar. Sci. 61, 774-781.

Venables, W.N., Ripley, B.D., 2002. Modern Applied Statistics with S, 4th ed. Springer Verlag, New York.

Wainwright, P.C., 1991. Ecomorphology: experimental functional anatomy for ecological problems. Am. Zool. 31, 680-693.

Wainwright, P.C., 1996. Ecological explanation through functional morphology: the feeding biology of sunfishes. Ecology 77, 1336-1343.

Wainwright, P.C., Richard, B.A., 1995. Predicting patterns of prey use from morphology of fishes. Environ. Biol. Fish. 44, 97-113.

Wainwright, P.C., Bellwood, D.R., Westneat, M.W., Grubich, J.R., Hoey, A.S., 2004. A functional morphospace for the skull of labrid fishes: patterns of diversity in a complex biomechanical system. Biol. J. Linn. Soc. 82, 1-25.

Webb, P.W., 2004. Response latencies to postural differences in three species of teleostean fishes. J. Exp. Biol. 207, 955-961.

Webb, P.W., Weihs, D., 1994. Hydrostatic stability of fish with swim bladders: not all fish are unstable. Can. J. Zool. 72, 1149-1154.

Westneat, M.W., 1995. Feeding, function, and phylogeny: analysis of historical biomechanics and ecology in labrid fishes using comparative methods. Syst. Biol. $44,361-383$. 